\title{
Cultural history and aesthetics of nursing care
}

\author{
José Siles González ${ }^{1}$ \\ Maria del Carmen Solano Ruiz²
}

\begin{abstract}
The aim of this study was to clarify the role of aesthetics in the organization and motivation of care through history. The guiding questions were: What values and aesthetic feelings have supported and motivated pre-professional and professional care? and Based on what structures has pre-professional and professional care been historically socialized? Primary and secondary sources were consulted, selected according to established criteria with a view to avoiding search and selection bias. Data analysis was guided by the categories: "habitus" and "logical conformism". It was found that the relation between social structures and pre-professionals (motherhood, religiosity) and professional aesthetic standards (professionalism, technologism) of care through history is evidenced in the caregiving activity of the functional unit, in the functional framework and the functional element. In conclusion, in social structures, through the socialization process, "logical conformism" and "habitus" constitute the aesthetic standards of care through feelings like motherhood, religiosity, professionalism, technologism and humanism.
\end{abstract}

Descriptors: History of Nursing; Aesthetics; Philosophy, Nursing.

\footnotetext{
${ }^{1}$ RN, BA in Pedagogics, Ph.D. in History, Professor, Departamento de Enfermería, Universidad de Alicante, España. E-mail: jose.siles@ua.es.

${ }^{2}$ RN, Ph.D. in Social and Cultural Anthropology, Professor, Departamento de Enfermería, Universidad de Alicante, España. E-mail: carmen.solano@ua.es.
} 


\section{A história cultural e a estética dos cuidados de enfermagem}

O objetivo deste artigo foi esclarecer o papel da estética na organização e motivação dos cuidados ao longo história. A seguir, são mostradas as perguntas norteadoras: quais foram os valores e sentimentos estéticos que fundamentaram e motivaram os cuidados préprofissionais e profissionais? E em quais estruturas têm sido socializados historicamente? Foram consultadas fontes secundárias e primárias, selecionadas de acordo com critérios estabelecidos para evitar viés de busca e seleção. A análise de dados foi guiada pelas categorias: habitus e conformismo lógico. Identificaram-se evidências da relação entre as estruturas sociais e os padrões estéticos pré-profissionais (maternidade, religiosidade) e profissionais (profissionalismo, tecnicismo) dos cuidados através da história em: a atividade cuidadora da unidade funcional, o referencial funcional e o elemento funcional. Conclui-se que as estruturas sociais, mediante o processo de socialização, o conformismo lógico e o habitus configuram os padrões estéticos dos cuidados, mediante sentimentos como: maternidade, religiosidade, profissionalismo, tecnicismo e humanismo.

Descritores: Historia da Enfermagem; Estética; Filosofia em Enfermagem.

\section{La historia cultural y la estética de los cuidados de enfermería}

El objetivo de este artículo fue clarificar el papel de la estética en la organización y la motivación de los cuidados en la historia. La preguntas orientadoras fueron: ¿En qué valores y sentimientos estéticos se han fundamentado y motivado los cuidados preprofesionales y profesionales? y ¿En qué estructuras, los cuidados preprofesionales y profesionales, se han socializado históricamente? Se consultaron fuentes secundarias y primarias seleccionadas de acuerdo con criterios establecidos para evitar sesgos de búsqueda y selección. El análisis de los datos se guió con las categorías: "habitus" y "conformismo lógico". Se encontró que la relación entre las estructuras sociales y los patrones estéticos preprofesionales (maternidad, religiosidad) y profesionales (profesionalismo, tecnologicismo) de los cuidados a través de la historia, se evidencia en la actividad cuidadora de la unidad funcional, en el marco funcional y en el elemento funcional. Se concluye que en las estructuras sociales mediante el proceso de socialización, el "conformismo lógico" y el "habitus" configuran los patrones estéticos de los cuidados mediante sentimientos como la maternidad, la religiosidad, el profesionalismo, el tecnologicismo y el humanismo.

Descriptores: Historia de la Enfermería; Estética; Filosofía en Enfermería.

\section{Justification}

Historians who have studied production modes as a fundamental source have forgotten about the incidence of esthetics and values to explain the existence of social classes in the framework of dialectical materialism or have subordinated it to its ideas, as noticed in the economic-philosophical writings of Marxism(1); likewise, to a great extent, specialties like women's history and gender studies have relegated the incidence of feelings, values and beliefs in the labor socialization process in general and in nursing care in particular. We refer to care considering nursing in its most classical and generalized sense as the most ancient art and the most modern science. This term covers pre-professional and professional nursing (which includes, as non-professional antecedents through history: care for survival, maternal care, delivery, perinatal care, breastfeeding and child care, among others). Although nursing care in its different historical phases has been linked with: social structures like the functional unit (tribe, family, professional corporation), spatial structures like the 
functional framework (camping, hospital primary care center), and social actors who assume the role of preprofessional and professional caregivers (woman, wife, member of religious order, nurse), which respond to aesthetical standards that have determined different form of organizing, applying and interpreting care - a void is observed in aesthetic knowledge on both preprofessional and professional care regarding their structural correspondences, that is: the feeling of parenthood and the tribal or family structure or the feeling of motherhood, the care professional's feeling or "professionalism" and the corporation or professional family. All of these entail their values and feelings, associated on their corresponding scale, whether tribal, family or professional. In other words, a great deficit exists in knowledge on the connections between the cultural pressure mechanisms (values, moral, myths, traditions, feelings and religions) that constitute the ethical standards corresponding to the structures implied in care. The goals in this study were as follows:

1) To clarify the role of aesthetics in care, assessing its incidence in the organization and motivation of preprofessional and professional care, from the perspective of the cultural history of nursing.

2) To identify the structures that have contributed to the organization, foundation and motivation of (preprofessional and professional) nursing care in the different historical phases, relating them with their corresponding aesthetic standards (nuclear feelings that motivate preprofessional and professional care actions).

\section{Premise or hypothesis}

Cultural history permits the study and analysis of values and feelings and their incidence in the organization and motivation of (pre-professional and professional), which is why it is pertinent to study the aesthetics of care.

The feelings of motherhood, altruism, charity and piety have served as the base sustaining the aesthetics of pre-professional care throughout a large part of nursing history.

Values project feelings, "subjective resonances" that constitute cultural pressure tools which determine the organization and motivation of (pre-professional and professional) care.

Research questions: What values and aesthetic feelings have supported and motivated pre-professional and professional care? and Based on what structures has pre-professional and professional care been historically socialized?

\section{State of the art}

The aesthetic theme has been monopolized for a long time by disciplines like philosophy, psychology and art. Feelings, however, are considered fundamental elements for analysis in nursing. Since classical antiquity, aesthetics has been a source of concern; philosophers in ancient Greece, however, did address the theme by identifying the form or idea of the good as the supreme value $^{(2)}$. From the poetical, dramaturgical and historical perspectives, aesthetics was interpreted as a logic of sensitivity ${ }^{(3)}$. Other authors reinterpreted the Platonic principle that "the good is beautiful", linking ethics with aesthetics in the framework of nursing care ${ }^{(4)}$. In fact, history has shown that, for a long time, care has been the responsibility of people who were in tune with supreme values like motherhood and religiosity ${ }^{(5-6)}$ and which have aesthetically determined the morphology and functionality of the social structures implied in care $^{(7)}$. Also, the coercive function of the values linked with aesthetics has been investigated and assessed as something innate and precise for people to accomplish the socially assigned functions, convinced that they are acting legitimately. Other researchers describe the cultural pressure mechanisms needed, for example, for mothers to dedicate themselves to housework, among which care is central(8).

Interpretive hermeneutics has contributed to the study of feelings, demonstrating that they constitute a universal reference for humanity, which permits a comparative analysis between aesthetics and hermeneutics(9). Based on this same interpretative context, it is affirmed that the artistic identity of any work derives from its potential understanding through a hermeneutic act, which takes place in the connection between the care act and the need to understand what it implies ${ }^{(10)}$. Cultural historians, most of whose origins lie in social history, study both the feelings and values of society and transmission and cultural pressure mechanisms. In the Birmingham School, an important group of cultural historians emerged which studied literature, the Mass Media and how they influence people's way of thinking and feeling, enhancing the standardization of mass aesthetics ${ }^{(11-12)}$. From another perspective, studies have focused on phenomena like the strong resistance to the change in women's role in the family and in religious members' role in a given order, both in the care context ${ }^{(13-14)}$. In nursing, the referential and organizing factor of feelings has been studied, departing from the feelings inspired by the biological 
nature itself in primitive cultures and in the structuring nature of this entire process in the construction of nursing knowledge, going deeper into the nature of this knowledge ${ }^{(15)}$. In a study on nursing knowledge patterns that can be considered a model, four levels can be classified: empirical scientific, ethical, personal and aesthetic(16). Countless researchers have followed this classification of nursing knowledge patterns ${ }^{(17-22)}$, from different perspectives, but respecting what is essential in the classification and the principles the same author established. Some years later, a study was published that critically analyzes Carper's contributions, and also manifests the positive aspects of his work, which adds a new pattern - the sociopolitical - which supposes, in line with Heidegger's concept of being "there", developed in "Being and Time", taking the historical, geographic, ideological and sociocultural context into account in the ways knowledge is structured ${ }^{(23)}$.

The new frontiers of nursing knowledge are addressed from a perspective that assumes the complexity of care $^{(24)}$. Other researchers ${ }^{(25)}$ have studied and dialectically analyzed nursing as an art. Also, various authors have looked at the aesthetics of care from different viewpoints; to give an example, based on ethics and philosophy, expressing the need for nursing to develop and apply professional spaces and strategies for the subjective expression of feelings ${ }^{(26)}$ and, based on poetry, socio-poetics and written prose, as a form of expressing and storing aesthetic knowledge produced in the intensity of nurse-patient interaction processes ${ }^{(27-29)}$. Other studies have contemplated, analyzed and reflected on iconographic art works as instruments to construct aesthetic knowledge on care ${ }^{(30-31)}$. The aesthetics of care and its contributive function to the adoption of a social model of values, traditions and feelings have been studied in media with a great transmission and cultural pressure potential, like movies ${ }^{(32)}$.

\section{Paradigm, theoretical framework and method used}

This study departs from the premises of Gadamer's hermeneutic paradigm, given its great potential for aesthetic interpretation, aiming to explain the slow historical processes that take place in the social structures implied in care and its aesthetics; therefore, it is relevant to take into account the principles of the socio-critical paradigm(33) and critical thinking as tools to analyze the transformation phenomenon of aesthetic standards in society and in daily life, as a consequence of the structural changes the aesthetics of care is experiencing, due to the cultural pressure mechanisms that influence the movement from a pre-professional to a professional care aesthetics(34).

The basic theoretical framework - cultural and aesthetic history - whose origins are the Birmingham school, is characterized by the study of society's feelings and values as well as transmission and cultural pressure mechanisms. To adequately understand cultural history, one needs to depart from a coherent idea of history (with regard to culture). History can essentially be interpreted in line with Aróstegui, who affirms: "the temporal quality contains everything that exists as well as its empirical manifestation"(35). Thus, nothing escapes from history as nothing exists unless over time. A holistic panorama of the historical discipline was offered by affirming that history should be considered the only science that is at the same time dynamic and global and which offers a synthetic view of the human phenomenon ${ }^{(36)}$. The following definition clarifies the relation between history and aesthetics as the core of human feelings: aesthetics is integrated in the temporal nature of care, to which it grants form and style, marking the trends that distinguish care over time in different cultures. On the other hand, according to Vilar, as a simultaneously dynamic and global science, history, which synthetically presents phenomena, has to study the evolution of feelings and values, and have they influence the aesthetical configuration of care. To clarify the theoretical care that inspired this study, a definition of cultural history needs to be provided, which is both comprehensive and precise and collects the most essential from the statements, through which one intended to express the characteristics of need, culture, care, anthropology, aesthetics and history. The cultural history of care could be defined as a specialty of historical science, which aims to study the human being immersed in his culture over time, taking into account all behaviors, ideas, feelings, symbols and meanings that occur in a given social, economic, family and labor context and which are implied in the process of attending to a human group's health needs ${ }^{(37)}$. The cultural history of care represents a pertinent tool to study the aesthetics of care in relation to cultural and axiological factors. Etymologically, the word aesthetics derives from the Greek (aisthetikê) "feeling, perception" and (aisthesis) "feeling, sensitivity". One can interpret aesthetics as the science that studies and investigates the systematic origin of pure feeling and its manifestation, which is art, as Kant affirms in his "Critique of Judgment". The basic social and mental 
structures that will be studied and analyzed from the perspective of the cultural and aesthetic history of care are, in line with Siles: 1- functional unit: family, religion, myths, science (social or mental structure that socializes and grants meaning to care); 2- functional framework: home, hospital, primary care center, temple (spatial structure where care is delivered); and 3- functional element: woman, wizard, witch, member of a religious order, professional (social actor responsible for care delivery) $)^{(15)}$.

\section{Method}

To avoid selection bias during the heuristic process, a protocol was established to assess the articles by theme, according to three filter levels: title, abstract and full contents. The time period set was between 1988 and 2010, during which papers could be consulted that were published in peer-reviewed journals, as well as monographs on the theme written in English, Spanish or Portuguese. The search was accomplished using descriptors that reflected the aims, hypothesis and research questions (aesthetics, care, aesthetics of care, nursing and aesthetics, cultural history of care, feelings and care, functional structures and care, art and care, knowledge standards and aesthetics) in secondary or related sources, which were selected because they permit searches according to previously established criteria (Cuiden, Cinahl, Medline, Bireme), from which the selected primary sources were extracted. The inclusion criteria, with a view to better adapting the study to its goals, were: studies that contained information about the aesthetics of care throughout history; studies on aesthetics with an integrative focus on the sentimental dimensions and nursing techniques; research that permitted analyzing the relations between the aesthetic standards and the functional structures implied in care (functional unit, functional framework and functional element); and studies that developed synthetic foci among cultural, aesthetic, physiological and axiological aspects. After a 60-day search period, in total, 102 initially selected publications were obtained, $58.82 \%$ of which were excluded after passing through the filter levels and after checking for compliance with the inclusion criteria. For categorization and data analysis, with a view to establishing the relations between aesthetic standard, feelings, values and aesthetic symbols, Bourdieu's term "habitus" and Durkheim's "logical conformism" were used(23). To proceed with the structural integration of the aesthetic standard from a care perspective, Siles' functional care structures were used: functional unit, functional framework and functional element ${ }^{(15)}$.

\section{Development of the theme value hierarchization as a cultural pressure mechanism and its relation with aesthetic care standards}

In a dim invisibility position - at least for traditional history - values, beliefs, feelings and symbols have influenced the manifest way care is organized. The universal nature of values corresponds to a collection of ideas that by itself is negligible if they are not ingrown in people who manifest them as a quality or attribute of their being. Thus, what is perceived of the values are the qualities of these depositaries: the beauty of a painting, the harmony of a melody, the tenderness of a mother taking care of her offspring, the religiosity of a member of a religious order (dedicates her life to helping the poor and ill), the professionality of a nurse with scientific education, among others. The German philosopher Max Scheller ranked values in the mid- $20^{\text {th }}$ century into four modes, in function of their duration and universality. Ranging from the most specific and localized to the most complex and universal forms of value, Scheller presents this classification, in which the strong interrelation between values and feelings is noticed. Health and disease, as well as force and emotional experiences, are integrated into the "vital values" and occupy a secondary level from the bottom to the top of the scale. The aesthetics of care could be integrated in the third level (the spiritual), while the type of interpretation of the causes as well as the treatments of health problems would be located at the highest level, which is the religious or profane(38) (Picture 1).

\section{N4: Religious values}

The sacred and the profane (supernatural or rational interpretation of care)

N3: Spiritual values

Aesthetic, Justice, Truth (Aesthetics of care)

N2: Vital values

Health/Disease/Wellbeing/Emotional experiences

N1: Sensitive values

Affect, pleasure, pain

Source: Ferrater Mora, J. Diccionario de la Filosofía. Barcelona: Círculo de Lectores; 1992.

Figure 1 - Hierarchization of values 
For people to accomplish socially assigned functions, coercion needs the artificial and vertical overlapping of values; this process is closely linked with human communication processes, technology and, mainly, with the feelings the Mass Media imply(5). The health and disease concepts have been categorized as vital values that produce feelings or "subjective resonances", integrated in symbols with aesthetic meanings that have represented and projected them on society, determining a particular care aesthetics(38). These values, their feelings (subjective resonances) and symbology, which influence the aesthetic configuration of care, have been subject to historical-cultural variations that constitute an important part of cultural history's research problem. One of the consequences of the historical-cultural variations in care is the change in values and feelings, ranging from motherhood to professionality and technique. The transformation of pre-professional care aesthetics structured in maternal values and feelings is replaced through a deconstruction process, enhanced by feminist thinking and critical thinking during the final third of the $19^{\text {th }}$ century and the first half of the $20^{\text {th }}$ century ${ }^{(7)}$. This new professional care aesthetics gradually finds support in the values and feelings technological rational thinking, science and professionalism provide ${ }^{(33-34)}$.

\section{A historical-cultural view on the relations between social structures and care aesthetics: logical conformism, habitus and aesthetic standards of nursing}

The structures in the organization of society whose function is to configure the aesthetics of care - such as the parental family, the professional family or corporativism and the mental structures rooted in religious or professional beliefs and values, have contributed to complement the (pre-professional and professional) caregiving function in society, and are motivated by a constellation of aesthetically meaningful symbols that give rise to feelings and values which are different - motherhood and the female world, the interior world distanced from bodily passions and weaknesses (but intensely burdened with the dogmas of religious symbolism), ethically regulated professionalism and centered on values and professional knowledge and beliefs - and flow towards the same end: care, although with distinguished aesthetics in function of the historical phase, that is, the aesthetics of pre-professional care (family, religion) and the aesthetics of professional care (corporativism or professional family and scientific knowledge and principles).
Nursing history contains aesthetic standards whose characteristics are conditioned by different types of values, for example magic, animism and religiosity (supernatural interpretation of illnesses and their consequent treatment in relation to those causes) and motherhood, altruism, solidarity, empirism and scientifism (natural, domestic, empirical, rational and scientific interpretation of care and its consequent treatment in relation to those causes).

Carper's knowledge standards, which are: empirical, ethical, personal and aesthetic, have different characteristics and objectives, but that does not mean that one can understand them as isolated entities. Instead they constitute interrelated and highly cross-sectional cores, influenced by religious, domestic, professional and scientific forms of thinking and feeling. Some authors have reduced the aesthetic knowledge pattern to little less than the "art" of knowing how to perform techniques or procedures. This aesthetic trend applied to care would result in care aesthetics exclusively centered on "knowhow" and care techniques or procedures. However, as Schiller observed, the aesthetic world also corresponds to empiricist sensualism and the feelings that have a place in each personal, professional, ethical and cultural experience. In this sense, care aesthetics goes beyond the purely technical, given that it is part of the world of values, feelings and the ethical-cultural aspects that constitute aesthetic experiences in care processes.

Cultural pressure is enchanced by the social and mental structures which, through the compulsory socialization of feelings, values, beliefs, myths and traditions, end up imposing - based on socio-political standards, a form of thinking, organization and action - everything related to care and contribute to the construction of a certain care aesthetics(39).

The functional unit, as a basic social structure of coexistence and socialization (family, religion, humanism, neopositivism or technological thinking, college or professional society, among others) is what determines the motivation for pre-professional and professional care, based on aesthetics that derives from the group's coexistence and socialization process (Picture 2). The functional unit is also fundamental in the acquisition of values, standards, beliefs, traditions and roles, among others. The aesthetic care standard is based on the feelings coming from the functional unit (motherhood, altruism, charity, solidarity, professionalism and technologism, among others.)

The functional framework is the spatial structure in which care is delivered and is determined by the aesthetic 
trends the functional unit has set (home-family, templereligion, religious hospital-religion, lay hospital-science/ technology and civil hospital-humanistic science).

The functional elements are the social actors in charge of the organization; they deliver care based on the aesthetic criteria established by the corresponding functional unit (woman-family, member of religious order-religion, nurse-family, nursing technicianprofession/science and holistic nurse-humanism).

\begin{tabular}{|c|c|c|c|c|}
\hline Functional unit & $\begin{array}{l}\text { Functional } \\
\text { framework }\end{array}$ & Functional element & $\begin{array}{l}\text { Aesthetic care standard and } \\
\text { feelings it is based on }\end{array}$ & Historical evolution \\
\hline $\begin{array}{l}\text { Tribe } \\
\text { Animism }\end{array}$ & Camping/ cave & $\begin{array}{l}\text { Woman } \\
\text { Wizard } \\
\text { Witch }\end{array}$ & Tribal (motherhood, magic) & Prehistory \\
\hline Family & Hone & Woman & Family (motherhood) & Antiquity \\
\hline Myths & Temple & $\begin{array}{l}\text { priest/priestess } \\
\text { Gods/goddesses }\end{array}$ & Roligious (chority oltruism) & Middle Ages \\
\hline Religion & Religious hospital & $\begin{array}{l}\text { Members of religious } \\
\text { orders }\end{array}$ & Rengious (criamity, antruism) & Renaissance \\
\hline \multirow{3}{*}{$\begin{array}{l}\text { Corporation/ } \\
\text { professional family }\end{array}$} & Outpatient clinic & & & XVIII century \\
\hline & Professional hospital & Profession & $\begin{array}{l}\text { Professional (technologism, } \\
\text { scientifism, professionalism) }\end{array}$ & Industrial Revolution \\
\hline & Health center & & & Contemporary Age \\
\hline
\end{tabular}

Source: Siles J. Historia de la enfermería. Alicante: Aguaclara; 1999

Figure 2 - Aesthetic structures and standards in the cultural history of nursing

Considering these structures and analyzing them in comparison with the feelings, values and beliefs that will drive the care socialization process, it is noticed how it is only based on the influence of feelings, symbols and values that women's "logical conformism" is understood, who during millennia have dedicated the central part of their lives to the same tasks. Thus, the feelings, symbols and values contain a utilitarian component that leads to the production and maintenance of the social structures that perform functions as important as pre-professional and professional care. Individuals' integration, which permits the functioning of these structures (the woman in the family, the member of a given religious order), happens unconsciously, contributing to the goal achievement of a plan. Women who take care of their children are driven by a maternal feeling that derives from the symbolic power of motherhood and determines these care practices, in which all those women who accomplish them through the observance of an inclination or cultural "habitus" are acknowledged as peers. According to Bourdieu, the "habitus" constitutes a mechanism to interiorize the classifications or categories of feelings that are culturally established. In the same line, to understand why the caregiving functions of social structures like the family and religious orders (like those dedicated to care for the ill) are still in force, it is extremely clarifying to turn to Durkheim's concept of "logical conformism"(13).

\section{Aesthetics as a theory for knowledge about the sensitive and its interpretation from a nursing perspective}

Before asserting that the cultural history of nursing has to focus on this or that part of human life (in this case the world of feelings), one needs to classify its characteristics through a pertinent epistemological and etymological study. The close connection between maternal feeling and (pre-professional) care aesthetics is proven when one analyzes the Anglosaxon word "nurse", which derives from nutrix and nutrire (feed); the aesthetic manifestation of the feeling of breastfeeding a baby is both universal and loaded with symbology and aesthetic meanings; to give an example: Venus in different places (in prehistory), Virgins giving the breast to or taking care of the child (antiquity, Middle Ages and renaissance), women giving the breast to or taking care of children (since antiquity until today), among others.

Aesthetic theory is part of philosophical science as a knowledge theory about the vulgar (the sensitive). Also, aesthetic knowledge is separated from the rational because it is based on the individuality of human sensitivity, but aesthetic ideas are necessary to represent rational ideas through the design of an aesthetic form (sensitive). When Gadamer sustains that the experience of art - among everything that takes us closer to nature and history - is what accomplishes communication in 
an immediate, close and familiar way, as if any meeting with a work of art would mean a meeting with ourselves, which affirms the universality of feelings. Aesthetics exceeds hermeneutics, which constitutes a bridge to save the historical, human or cultural distance among people, while aesthetics directly breaks this separation due to the universality of feelings; aesthetic knowledge of care outrises hermeneutics' potential for immediate communication ${ }^{(39)}$. Aesthetic ideas are halfways between instinct and the conceptual, between sensitivity and understanding, they do not produce knowledge but regulate it by shaping it; consequently, the conceptst of care, disease, health, pain, death and others are regulated by their corresponding aesthetic forms. Care aesthetics looks after that part of common (sensitive) communication that results from care practice and is closely interrelated with the perceptive abilities integrated in the five senses of human beings ${ }^{(40-41)}$. Nurses who take care of elderly people experience individual feelings that are no longer their particular feelings and sprout from these elderly people they are taking care of. However, when one can observe a painting, see a movie, read a novel or listen to a song whose messages or plots contain a representation of the rational idea "care for the elderly", in any of its infinite spatial, temporal, personal or cultural variations, some feelings will emerge that essentially are universally shared.

\section{Aesthetics and its sources in the cultural history of care}

The above epistemological reflection has made it easier to clarify the aesthetic nature of nursing knowledge, one of the dimensions of this knowledge that has practically remained invisible to professional and scientific nursing. Like in the case of other kinds of exclusion, such as: gender, race and social class, among others; history is responsible for recovering from the past this "treasure" that is part of the care collection ever since human beings have existed - the feelings implied in care - and for contributing to a reinterpretation of ways of professional and scientific thinking in nursing.

As a research problem, feelings are as crucial to understand the causes of uprisings as the facts that provoke them(42). The history of feelings, integrated in the cultural history of care, can contribute to answer questions like: What maintains mothers linked to the domestic and care environment for so long? Is this only due to the submission provoked by man's power? When analyzing the feelings integrated in care, cultural historians focusing on care identify the care aesthetics in each historical phase.

\section{Discussion}

The consideration of the socio-political knowledge standards contributes to contextualize the interpretation of the role of aesthetics in the evolution and organization of care(23); this contextualization, however, demands studies focused on more specific cultural contexts that permit overcoming the potential ethnocentrism of this work, whose more generical and essentialist nature offers a global view on the phenomenon. Although many authors consider the aesthetic knowledge standard fundamentally technical(22), in this study, the aesthetics of care is interpreted as a knowledge standard that integrates the sensualist (corresponding to the world of feelings) and rationalist (more characteristic of the technical context) dimensions. According to Durán de Villalobos, a large majority of nursing professionals circumscribe the aesthetics or art of care solely to the technical dimension, although authors like Chinn \& Kramer bet on an integration that reconciles both dimensions: the sentimental or sensualist and the rational or technical. Other authors, departing from the universal contemplation of human beings' core feelings (motherhood, piety, altruism and professionalism, among others), these demonstrate that what is essential about care does not originate in know-how but in the feelings motivating that activity ${ }^{(39)}$. Motherhood, altruism, charity, piety and other feelings have paradoxically influenced both the development and delay in the integration of nursing care into the professional framework. This reveals the dialectic nature of aesthetics, due to the fact that, according to the historical conjuncture, its function has been interpreted as driving or hindering care.

In the driving function, in a pre-industrial and even industrial society in which no alternative social structures exist (church: care delivered by members of religious orders and state: care delivered by nursing professionals) to replace the family's caregiving function; the feeling of motherhood has constituted the core that maintained group coherence through the structure of parenthood and affective bonds. Motherhood inspires feelings through which the entire parenthood system gets organized and the basic social structure of coexistence and socialization, which is the family, is constructed, so linked with care, with the sexual distribution of work and with its essential role in the general satisfaction of human beings' needs in daily life (food, hygiene, sleep, relaxation, safety, affect, learning, among others). 
In the hindering function, both the aesthetic and the religious feeling of motherhood turn into obstacles to care professionalization and the birth of nursing as an academic discipline.

\section{Conclusion}

The obtained results allow us to affirm that cultural history - focusing on the feelings, beliefs and values that make them sprout in a specific social and cultural context - constitutes a pertinent tool for the study and analysis of the feelings implied in care and their subjective resonances (beliefs, values), i.e. of care aesthetics.

The feelings of motherhood, altruism, charity and piety have functioned as the base and motivation for the caregiving function during a large part of preprofessional nursing's history.

The link between the feelings and values is produced through their social hierarchization and functions as a tool to exert cultural pressure on members, who get socialized by sharing the same care aesthetics.

Social, cultural and aesthetic factors are fundamental to construct the history of nursing. Social structures like the family, religious groups and corporate colleges have enhanced pre-professional (motherhood, altruism, piety, charity) and professional values and feelings (professionalism, technologism, humanism in care), which constituted the basic pillars that have granted meaning and have served to organize, support and enhance the motivation for care aesthetics in different historical phases.

Aesthetic standards have influenced the organization of pre-professional and professional care throughout history. The cultural and aesthetic history of nursing offers an integrative view of structures and aesthetic standards which, due to their dialectic nature, have served as drivers and obstacles for care, in line with historical conjunctures.

The concepts of care and nursing constitute values that arouse feelings - "subjective resonances" - integrate in symbols that have represented and projected them on a dynamic society subject to historical and cultural variations.

Concepts like "habitus" and "logical conformism" contribute to the understanding of the slow transition process from domestic-religious care, marked by aesthetic symbolic systems with categories like motherhood, feminimity and religiosity, to the professional and scientific context.
To understand why the care functions of social structures like the family and religious orders (like those dedicated to care for the ill) have continued, Durkheim's concept of "logical conformism" is extremely useful; this concept explains the interiorization process of culturally established categories: motherhood, femininity, masculinity, religiosity and professionality, among others. Considering the universality of the feelings that motivate care actions/conducts, "know-how" (technique) does not constitute the essence, but the consequence of care aesthetics.

Aesthetic values and feelings have supported and motivated pre-professional and professional care, meeting with structures that socialize feelings, such as: motherhood, piety, altruism, empirism, technologism, professionalism, scientifism and humanism.

\section{References}

1. Sánchez Vázquez A. Las ideas estéticas de Marx. Madrid: siglo XXI: 2006.

2. Palacios A. Los valores en medicina. Hacia una axiología del ethos médico. Rev Mex Reumat. 2002;17(2):157-60.

3. Schiller F. Kallias. Cartas sobre la educación estética del hombre. Barcelona: Antrhropos; 2007.

4. Busquets E. Ética y estética del cuidar. Revista Rol de enfermería. 2008;31(11):28-34.

5. Pross H. Estructura simbólica del poder: teoría y práctica. Barcelona: Editorial Gustavo Gil; 1980

6. Martínez Pérez M. Arte y ciencia de la enfermería. Rev Méd Electrón. 2008; [acesso 12 março 2010]. 30(1). http://www.revmatanzas.sld.cu/revista\%20medica/ ano\%202008/vol1\%202008/tema15.htm.

7. Siles J. La eterna guerra de la identidad enfermera: un enfoque dialéctico y deconstruccionista. Index Enferm. 2005;14(50):7-9.

8. Pross H. Atrapados en la red mediática. Orientación en la diversidad. Guipúzcoa: Argitaletxe; 2000.

9. Gadamer HG. Estética y hermenéutica. Rev Filosofía. 1996;3(12):5-9.

10. Gadamer HG. La actualidad de lo bello. Barcelona: Paidós; 1998.

11. Thompson EP. Costumbres en común. Barcelona: Crítica; 2000.

12. Williams R. Historia y cultura común. Madrid: Ediciones Catarata; 2008.

13. Herrera S. Sobre las formas de clasificación en Durkheim y Bordieu. Voces y Contextos. 2006;1(2):5-12. 
14. Bordieu P. La Distinción. Madrid: Taurus; 1988.

15. Siles J. Historia de la enfermería: una aportación epistemológica desde la perspectiva cultural de los cuidados. Cultura de los Cuidados. 2008;(12)24:5-7.

16. Carper B. Fundamental patterns of knowing in nursing. Adv Nurs Sci. 1978;1(1):13-23.

17. Chinn PL, Watson J. ed. Art and Aesthetics in Nursing. New York: National League for Nursing Press; 1994.

18. Berckman A. A personal journal of caring throught esthetic knowing. Adv Nurs Sci. 1994;17(1):71-9.

19. Gutiérrez E. Patrón de conocimiento estético. La investigación y el cuidado en América Latina. Bogotá: Universidad Nacional de Colombia; 2005.

20. Silva MC, Sorrell JM, Sorrell CD. From Carper's patterns of knowing to ways of being: an ontological philosophical shift in nursing. Adv Nurs Sci. 1995; 18(1):34-9.

21. Sorrell JM. Remembrance of things past throught writting: esthetic patterns of knowing in nursing. Adv Nurs Sci. 1994;17(1):60-70.

22. Durán de Villalobos M. La ciencia, la ética y el arte de enfermería a partir del conocimiento personal. Aquichan. [periódico na Internet]. 2005; [acesso 12 março 2010].

5(1) http://aquichan.unisabana.edu.co/index.php/ aquichan/article/view/62

23. White J.Patterns of knowing:review, critique and update. Adv Nurs Sci. 1995;17(4):73-86.

24. Edwards S. Nursing Knowledge: Defining New Boundaries. Nurs Stand. 2002;17(2):40-4.

25. Johnson JL. Dialectical analysis concerning the rational aspect of the art of nursing. Image J Nurs Sch. 1996;28(2):169-75.

26. Teixeira ER. O ético e o estético nas relações de cuidado em enfermagem. Texto Contexto Enferm. 2005;14(1):89-95.

27. Birx E. The poetry of nursing, I Clin Nurse Spec. 1994;8(6):292-93.

28. Siles J, editor Antropología narrativa de los cuidados. Alicante: Consejo Valenciano de Enfermería; 2000.

29. Santos ID, Gauthier J, Almeida de Figueiredo NMa, De Melo Tavares CM, Souza Brandão, E, Ferreira Santana, R. La perspectiva estética en el cuidar/educar junto a las personas: apropiación y contribución de la socio-poética. Texto Contexto Enferm. 2006;15 (spe):31-8.

30. Miralles MT, Durán M. El milagro de San Juan de Dios, de Murillo. Cult Cuid. 2006; 10(20):50-4.

31. Santos Alves MaD, Batista Oriá MO, Santana Franco E, Costa M, Teixeira Barroso MG.. Historia de la enfermería registrada en las artes plásticas: del siglo XVI al siglo XX. Texto Contexto Enferm. 2005;14(4):513-9.
32. Siles J. Fuentes etnográficas e historia de la enfermería. Híades. 2008;1(10):111-38.

33. Habermas J. Ciencia y técnica como ideología. Madrid: Tecnos; 2007.

34. Habermas J. (2009) Historia crítica de la opinión pública: la transformación estructural de la vida privada. Barcelona: Editorial Gilli; 2009.

35. Aróstegui J. La investigación histórica: teoría y método. Barcelona: Crítica; 2004.

36. Vilar P. Iniciación al vocabulario de análisis histórico. Barcelona: Crítica; 1999.

37. Siles J, Cibanal L, Vizcaya F, Gabaldón E, Domínguez JMo, Solano C, García E. Una mirada a la situación científica de dos especialidades esenciales de la enfermería contemporánea: la antropología de los cuidados y la enfermería transcultural. Cultura de los Cuidados 2001;5(10):72-87.

38. Scheller M. El saber y la cultura. Madrid: Ediciones Escolar.Com; 1999.

39. Gadamer HG. Estética y hermenéutica. Rev Filosofía. $1996 ; 3(12): 5-9$

40. Wosny AM, Erdmann A, Belli P Filho, Leite JL. The aesthetics of smells: the sense of smell and nursing. Rev. Latino-Am. Enfermagem. 2008;16(2):320-3.

41. Terra MG, Goncalves LHT, Santos EKA, Erdman AL. Sensibility in the Relations and Interactions of Teaching and Learning to Be and Do Nursing. Rev. Latino-Am. Enfermagem. 2010;18(2):203-9.

42. Thompson EP. Tradición, revuelta y consciencia de clase. Barcelona: Crítica; 1989.
Received: Ago. 31 2010 Accepted: Mar. 22 2011 